Research Article

\title{
Profile of Cervical Smears in Andaman and Nicobar Islands
}

\author{
Vivin Vincent', MK Saha ${ }^{2}$ \\ ${ }^{1}$ Associate Professor, Department of Community Medicine, ANIMS, Port Blair, Andaman and Nicobar, India. \\ ${ }^{2}$ Professor, Department of Obstetrics and Gynaecology, ANIMS, Port Blair, Andaman and Nicobar, India. \\ DOI: https://doi.org/10.24321/2454.8642.201909
}

I $\quad \mathbf{N} \quad \mathbf{F} \quad \mathbf{O}$

Corresponding Author:

MK Saha, Department of Obstetrics and Gynaecology, ANIMS, Port Blair, Andaman and Nicobar, India.

E-mail Id:

diraniims@gmail.com

Orcid Id:

https://orcid.org/0000-0001-6859-9484

How to cite this article:

Vincent V, Saha MK. Profile of Cervical Smears in Andaman and Nicobar Islands. Rec Adv Path Lab Med 2019; 5(2): 18-21.

Date of Submission: 2019-06-29

Date of Acceptance: 2019-07-30

\section{$\begin{array}{llllllll}\mathbf{A} & \mathbf{B} & \mathbf{S} & \mathbf{T} & \mathbf{R} & \mathbf{A} & \mathbf{C} & \mathbf{T}\end{array}$}

Background: About one million deaths amongst world's women population are attributed to cancer cervix every year. Pap smear is a widely accepted screening method used to detect potentially precancerous and cancerous processes in the cervix.

Objective: To find out the prevalence of abnormal pap smear conditions in women attending Gynaecology out-patient department.

Methods: This retrospective study was carried out in the Gynaecology unit during January $1^{\text {st }} 2018$ to December $31^{\text {st }} 2018$ on 537 pap smear samples. The data was entered in excel and was presented in percentages.

Results: $43.45 \%$ had complaints of white discharge. 5.5\% had epithelial cell abnormality; around $85 \%$ were negative for intraepithelial lesion or Malignancy. $4.35 \%$ of the study population had Atypical squamous cells high grade cannot be excluded ASC-H and also Adenocarcinoma. None had atypical glandular cells.

Conclusion: Regular screening camps should be organized by local government and medical fraternity to benefit women to reach the whole community.

Keywords: Cervical Smear, Cancer, Women, Pap Smear

\section{Introduction}

About one million deaths amongst world's women population are attributed to cancer cervix every year. Cervical cancer has taken a second place amongst malignancies that affects women, first leading is breast cancer. ${ }^{1}$ If diagnosed and treated earlier, and morbidity may be reduced by $70 \%$ and mortality by $80 \%$. The Papanicolaou test also known as Pap test, Pap smear, cervical smear or smear test is a screening method used to detect potentially precancerous and cancerous processes in the cervix. ${ }^{1,2}$ Poor living conditions, lack of hygiene, early age of first intercourse, multiple sexual partners and Human Papillomavirus (HPV) infections are major etiological factors for the development of cervical carcinoma. ${ }^{3}$ Epidemiological studies suggest that HPV is associated with a 10-fold or greater risk of cervical neoplasia than controls. ${ }^{4}$ It is now known that certain strains (16 and 18) of HPV are present in most cervical cancers, several newer strains as etiological factor are under investigation. ${ }^{5}$ Papanicolaou (Pap)-stained cervical cytology smears also detect the presence of various genital infections such as Trichomonas vaginalis, Candida species, actinomycetes such as organisms, bacterial vaginosis, Neisseria gonorrhoeae, Herpes Simplex Virus (HSV) and HPV. ${ }^{2}$ 


\section{Objective}

To find out the prevalence of abnormal pap smear conditions in women attending Gynaec OPD.

\section{Methods}

This retrospective study was carried out in the Gynaecology unit of GB pant Hospital, ANIMS, Port Blair. All patient records who underwent pap smear during January $1^{\text {st }} 2018$ to December $31^{\text {st }} 2018$ were included in the study. A total of 537 pap smear were performed. A total of 125 smears were excluded because of improper documentation/ did not fit in the inclusion and exclusion criteria in their request forms. Hence finally 412 pap smear results were included in the study.

\section{Inclusion Criteria}

Women above 20 years of age.

\section{Exclusion Criteria}

- Women below 20 years.

- Women without sexual exposure.

- Women who are pregnant.

- Not given informed consent.

The pap smear was done in gynaec OPD using Ayers spatula. Smear from ectocervix was taken using broad end of the spatula rotating it 360 degrees. Sample from endocervix was taken using cytobrush and smear was made on a separate slide. After labelling slides were kept in 95\% Ethanol fixative and sent to the laboratory. Evaluation was done using Bethesda system. The results were discussed in percentages.

\section{Result}

Majority of study population, $31.8 \%$ were in the age group of 30-40 years. It was followed by $40-50$ years age group (around 24\%) and 50-60 years (around 20\%). (Table 1). Table 2, shows that only $27.43 \%$ of females have done routine screening while the rest did pap smear for some indications. $43.45 \%$ came for complaints of white discharge. Cytological diagnosis of PAP smears are shown in Table 3. Around $5.5 \%$ had epithelial cell abnormality; around $85 \%$ were negative for intraepithelial lesion or Malignancy.

Table I.Distribution of study population according to age

\begin{tabular}{|c|c|c|}
\hline Age group & Frequency & Percentage \\
\hline $20-30$ & 68 & 16.5 \\
\hline $30-40$ & 131 & 31.80 \\
\hline $40-50$ & 98 & 23.80 \\
\hline $50-60$ & 82 & 19.90 \\
\hline$>60$ & 33 & 8 \\
\hline Total & $\mathbf{4 1 2}$ & $\mathbf{1 0 0}$ \\
\hline
\end{tabular}

Table 2.Indications for performing PAP smear

\begin{tabular}{|c|c|c|}
\hline Reason & Frequency & Percentage \\
\hline Routine screening & 113 & 27.43 \\
\hline Chronic white discharge & 179 & 43.45 \\
\hline $\begin{array}{c}\text { Unhealthy cervix } \\
\text { Abnormal uterine } \\
\text { bleeding }\end{array}$ & 35 & 8.50 \\
\hline $\begin{array}{c}\text { Intermenstrual spotting } \\
\text { Others }\end{array}$ & 33 & 4.12 \\
\hline
\end{tabular}

Table 3.Cytological diagnosis of PAP smears done

\begin{tabular}{|c|c|c|}
\hline Diagnosis & Frequency & Percentage \\
\hline Unsatisfactory & 37 & 8.98 \\
\hline $\begin{array}{c}\text { Negative for intraepithelial } \\
\text { lesion or Malignancy }\end{array}$ & 352 & 85.44 \\
\hline Epithelial cell abnormality & 23 & 5.58 \\
\hline Total & $\mathbf{4 1 2}$ & $\mathbf{1 0 0}$ \\
\hline
\end{tabular}

Table 4.Distribution of study population reported as negative for intraepithelial lesion or malignancy on Pap smear

\begin{tabular}{|c|c|c|}
\hline Cytology diagnosis & Frequency & Percentage \\
\hline Normal & 194 & 55.10 \\
\hline Nonspecific inflammation & 38 & 10.80 \\
\hline Bacterial Vaginosis & 37 & 10.51 \\
\hline Trichomoniasis & 21 & 5.97 \\
\hline Candida & 43 & 12.22 \\
\hline HSV & 2 & 0.57 \\
\hline Atrophic & 17 & 4.83 \\
\hline
\end{tabular}

Table 4, shows that of those who were declared negative for intraepithelial lesion or malignancy around $55 \%$ had normal smear and the rest had some infections. Non-specific inflammation, bacterial vaginosis and trichomoniasis were around $10 \%$, while candida was $12 \%$. Around $5 \%$ had atrophic changes. HSV infection was found in not even one percent of the study population.

Table 5.Pattern of epithelial cell abnormality in the study population

\begin{tabular}{|c|c|c|}
\hline ECA abnormality & Frequency & Percentage \\
\hline $\begin{array}{c}\text { Atypical squamous cells of } \\
\text { undetermined significance- } \\
\text { ASCUS }\end{array}$ & 5 & 21.72 \\
\hline $\begin{array}{c}\text { Atypical squamous cells } \\
\text { high grade cannot be } \\
\text { excluded ASC-H }\end{array}$ & 1 & 4.35 \\
\hline
\end{tabular}




\begin{tabular}{|c|c|c|}
\hline $\begin{array}{c}\text { Atypical glandular cells of } \\
\text { undetermined significance }\end{array}$ & 2 & 8.70 \\
\hline $\begin{array}{c}\text { Low grade squamous } \\
\text { intraepithelial lesions }\end{array}$ & 7 & 30.44 \\
\hline $\begin{array}{c}\text { High grade squamous } \\
\text { Intraepithelial Lesions }\end{array}$ & 4 & 17.40 \\
\hline Squamous cell carcinoma & 1 & 4.35 \\
\hline atypical glandular cells & 0 & 0 \\
\hline Adeno in situ & 2 & 8.7 \\
\hline Adenocarcinoma & 1 & 4.35 \\
\hline
\end{tabular}

Pattern of Epithelial cell abnormality in the study population is discussed in Table 5. Out those who had epithelial cell abnormality; around $30 \%$ had low grade squamous intraepithelial lesions while around $17 \%$ had high grade squamous intraepithelial lesions and $22 \%$ had atypical squamous cells of undetermined significance-ASCUS.4.35\% of the study population had Atypical squamous cells high grade cannot be excluded ASC-H and also Adenocarcinoma. None had atypical glandular cells.

\section{Discussion}

Majority of study population were in the age group of 30-40 years. Similar results were found by Mishra P et al. ${ }^{6}$

Only $27.43 \%$ of females have done routine screening while the rest did pap smear for some indications. $43.45 \%$ came for complaints of white discharge. Mishra P et al. ${ }^{6}$ reported only $15.15 \%$ were asymptomatic in his study and $52 \%$ had complaints of white discharge. In another study done by Vijaya Lakshmi P, Sree Gouri SR ${ }^{1}$ the prevalence of white discharge and Pelvic Inflammatory Disease was 35\%. Similar results were found by Verma A et al. ${ }^{7}$

In those who were declared negative for intraepithelial lesion or Malignancy around 55\% had normal smear and the rest had some infections. Bacterial vaginosis and trichomoniasis and non-specific inflammation were around $10 \%$, while candida was $12 \%$. Nayir T et al. ${ }^{8}$ in his study on turkey found around $72 \%$ inflammation. Similar results were observed by Vijaya Lakshmi P, Sree Gouri SR (67\%), ${ }^{1}$ and Kulkarni PR et al ${ }^{9}$. Lawley TB et al. ${ }^{10}$ observed a lower rate of $14.3 \%$ inflammatory smears.

Over all epithelial cell abnormality was $5.5 \%$ in our study. $1.7 \%$ had low grade squamous intraepithelial lesions, around $1 \%$ had high grade squamous intraepithelial lesions and atypical squamous cells of undetermined significance ASCUS was found in $1.21 \%$. Similar results were found in Elit L et al., ${ }^{11}$ Murillo $R$ et al. ${ }^{12}$ and Bamanikar SA et al., ${ }^{13}$ Shaki P et al. ${ }^{14}$ and Patel MM et al. ${ }^{15}$ showed a higher prevalence.

\section{Conclusion}

Cervix carcinoma is a preventable disease, Pap smear testing is a very useful, simple, economical, and safe tool to detect preinvasive cervical epithelial lesion with a reasonable specificity and sensitivity. In developing country like India, the regular screening camps should be organized by local government and medical fraternity to benefit women to reach the whole community

\section{Conflict of Interest: None \\ References}

1. Vijaya Lakshmi P, Sree Gouri SR. Study and analysis of two hundred cervical PAP smears in our hospital. International Journal of Contemporary Medical Research 2016; 3(9): 2787-2789.

2. Bamanikar SA, Baravkar D, Chandanwale S et al. Study of cervical cytology and its correlation with clinical and histopathological findings. Clin Cancer Investig J 2016; 5(5): 403-408.

3. Schiffman MH, Brinton LA. The epidemiology of cervical carcinogenesis. Cancer 1995; 7610 Suppl: 1888-1901.

4. Bosch FX, Manos MM, Muñoz N et al. Prevalence of human papillomavirus in cervical cancer: A worldwide perspective. International Biological Study on Cervical Cancer (IBSCC) Study Group. J Natl Cancer Inst 1995; 87(11): 796-802.

5. Chatterjee R, Roy A, Basu S. Detection of type specific human papillomavirus (HPV) DNA in cervical cancers of Indian women. Indian J Pathol Microbiol 1995; 38(1): 33-42.

6. Mishra P, Thapa R, Dinkar AK. A study on cervical cancer screening using pap smear in urban area in state of Meghalaya, India. Int J Reprod Contracept Obstet Gynecol 2018; 7(8): 3113-3116.

7. Verma A, Verma $\mathrm{S}$, Vashist $\mathrm{S}$ et al. A study on cervical cancer screening in symptomatic women using Pap smear in a tertiary care hospital in rural area of Himachal Pradesh, India. Middle east Fertility Society Journal 2017; 22(1): 39-42.

8. Nayir T, Okyay AR, Nizlican E et al. Cervical cancer screening in an early diagnosis and screening centre in Mersin, Turkey. Asian Pac J Cancer Prev 2015; 16: 6909-6912.

9. Kulkarni PR, Rani H, Vimalambike MG et al. Opportunistic screening for cervical cancer in tertiary hospitalin Karnataka, India. Asian Pac J cancer Prev 2013; 14(9): 101-105.

10. Lawley TB, Lee RB, Kapela R. The significance of moderate and severe inflammation on class I Papanicolaou smear. Obstet Gynecol 1990; 76: 997-999.

11. Elit L, Baigal G, Tan J et al. Assessment of 2 cervical screening methods in Mongolia: Cervical cytology and visual inspection with acetic acid. J Low Genit Tract Dis 2006; 10(2): 83-88.

12. Murillo R, Luna J, Gamboa O et al. Cervical cancer 
screening with naked-eye visual inspection in Colombia. Int J Gynaecol Obstet 2010; 109(3): 230-234.

13. Bamanikar SA, Baravkar DS, Chandanwale SS et al. Study of cervical pap smears in a tertiary hospital. Indian Medical Gazette 2014, 250-254.

14. Shaki O, Chakrabarty BK, Nagaraja N. A study on cervical cancer screening in asymptomatic women using Papanicolaou smear in a tertiary care hospital in an urban area of Mumbai, India. J Family Med Prim Care 2018; 7(4): 652-657.

15. Patel MM, Pandya AN, Modi J. Cervical Pap smear study and its utility in cancer screening, to specify the strategy for cervical cancer control. National Journal of Community Medicine 2011: 2(1): 49-51. 